\title{
Subject Islands are Different
}

\section{Citation}

Polinsky, Maria, Carlos Gomez Gallo, Ekaterina Kravtchenko, Adam Milton Morgan, and Anne Sturgeon. Forthcoming. Subject islands are different. In Experimental Syntax and Islands, ed. Jon Sprouse.

\section{Permanent link}

http://nrs.harvard.edu/urn-3:HUL.InstRepos:5131512

\section{Terms of Use}

This article was downloaded from Harvard University's DASH repository, and is made available under the terms and conditions applicable to Other Posted Material, as set forth at http:// nrs.harvard.edu/urn-3:HUL.InstRepos:dash.current.terms-of-use\#LAA

\section{Share Your Story}

The Harvard community has made this article openly available.

Please share how this access benefits you. Submit a story.

\section{Accessibility}




\title{
Subject islands are different
}

\author{
Maria Polinsky ${ }^{\mathrm{a}}$, Carlos Gómez Gallo ${ }^{\mathrm{a}}$, Peter Graff ${ }^{\mathrm{b}}$, Ekaterina Kravtchenko ${ }^{\mathrm{c}}$, Adam \\ Milton Morgan ${ }^{c}$, Anne Sturgeon ${ }^{\mathrm{a}}$ \\ (Harvard University ${ }^{\mathrm{a}}, \mathrm{MIT}^{\mathrm{b}}$, University of California at Santa $\mathrm{Cruz}^{\mathrm{c}}$ )
}

\section{Introduction}

Syntactic islands vary in the degree of their opacity, with the well-known contrast between strong and weak islands (Cinque 1990, Rizzi 1990, 2001, Szabolcsi and Zwarts 1993, a.o.). Until recently, decisions about the strength of particular islands relied on individual judgments of the researcher or cursory interviews with fellow linguists; most judgments have been based on English. Some islands, for instance adjuncts, have come

\footnotetext{
* We would like to thank John Bailyn, Ivano Caponigro, Shin Fukuda, Grant Goodall, Vera Gribanova, Robert Kluender, Terje Lohndal, Eric Potsdam, Nina Radkevich, Greg Scontras, William Snyder, Jon Sprouse, Peter Svenonius, Yakov Testelets, Matt Wagers, an anonymous reviewer, and the audiences of the Syntax Lab at UC Santa Cruz, FASLXIX, and the University of the Basque Country for their extremely constructive comments and suggestions. This research was supported in part by the Davis Center at Harvard and the National Heritage Language Resource Center at UCLA. All errors are our sole responsibility.
} 
out uniformly strong and, as a result, have given researchers confidence in the notion of syntactic opacity (but see Truswell 2007 for a subset of adjuncts which are transparent for semantic reasons). Other islands show much more variation, both within English and across the few other languages that linguists have considered. Subject islands belong to this latter category, and their degree of opacity has been the cause of disagreement among linguists.

Starting with English, extraction out of subjects shows a range of acceptability depending on the predicate, cf. the following examples based on Chomsky (2008): ${ }^{1}$

(1) a. It was the CAR (not the TRUCK) of which the driver arrived late/was awarded a prize.

b. *It was the CAR (not the TRUCK) of which the driver_caused a riot.

The acceptability of examples such as (1a) has also been supported by experimental work (Hiramatsu 1999, 2000), which compared adjunct islands with subjects of unaccusatives, and showed that the latter were fairly transparent.

From a theoretical standpoint, the acceptability of examples such as (1a) follows from accounts according to which extraction targets the base position of a constituent (Huang 1982; Chomsky 1986; Merchant 2001; a.o.). Assuming the general principle that extraction should be possible from internal arguments only, the tolerability of (1a) is no

1 In the examples below, the constituent from which extraction takes place is shown in bold, and the extraction site is represented atheoretically as a gap (underscore). 
longer surprising: extraction takes place out of the subject of an unaccusative, whose base position is that of an internal argument.

However, even if this account is on the right track, there is no arguing that examples like (1a) or (2a), where the subject undergoes subextraction, are perceived as degraded compared to those with subextraction out of objects (2b). In both cases the extraction targets an internal argument. This suggests that the base position alone may not be sufficient to account for island effects.

(2) a. ??What did [a bottle of __ ] appear in the kitchen?

b. What did she break [a bottle of __ ] in the kitchen?

Another trend in the theoretical literature has to do with motivating island effects by "freezing," which is the conception that once a constituent has moved, it becomes an island. Thus extraction out of a moved constituent is impossible. Three main approaches to freezing are summarized in (3): 


\section{(3) Main approaches to freezing}

a. GENERALIZED FREEZING: any type of movement makes a constituent opaque for extraction (Takahashi 1994, Stepanov 2007)

b. CRITERIAL FREEZING: only movement to an A-bar position makes a constituent opaque; such movement does not block subextraction (Rizzi 2006, 2007; Rizzi and Shlonsky 2007)

c. FEATURE-DRIVEN FREEZING: only some types of movement, in particular movement to check Case, lead to opacity of the moved constituent (Boeckx 2008, Lohndal 2011).

The English data suggest that freezing may be implicated, but freezing alone cannot handle all the facts. In terms of subject islands, freezing can explain the ungrammaticality of (1b) but not the acceptability of (1a). An additional complication for freezing comes from the theoretical side: given the internal subject hypothesis (Kuroda 1988), all subjects have to move, which suggests that freezing, at least in the sense of (3a), should apply across the board. Nevertheless, not all subjects seem to be equally strong islands, and this is what we will explore further in this paper.

With base position and freezing established as two approaches to subject islands, we can now move on to our project: exploring (sub)extraction out of subjects with the help of quantitative methods. We use these methods in order to obtain a comprehensive body of judgments that controls for individual differences among speakers and provides us with reliable data that can feed back into syntactic theory. We ask the following questions: 
(4) a. Are all subject islands equally opaque?

b. If not, does the strength of the island depend on the base position (co-varied with the predicate type) or on the derived position of the subject?

To address these questions, we will consider subject islands in English and Russian; each language makes a unique contribution. English is important because extensive work on subject island permeability has already been conducted. Hiramatsu (2000) examined English subextraction and found that while subject islands are permeable, adjunct islands are not; her work, however, only considered unaccusative predicates (see also Goodall 2004, Braze 2002). Snyder (2000) and Francom (2009) both found satiation effects in subject islands; Sprouse (2009), using the same experimental design as Snyder (2000), found no satiation effects. The emerging picture is one of empirical confusion: are subject islands permeable or opaque? Depending on one's theoretical take on subject islands, it is also important to ascertain whether all types of subjects should be assessed for islandhood, or only those subjects that originate as external arguments.

The syntactic design of English does not help much in answering all these questions: most subjects appear preverbally (expletive subject constructions being a notable exception), so it is possible that (sub)extraction is sensitive both to freezing effects and to base position.

Russian is a good test case for the role of structural position, as it has reliable unaccusativity diagnostics, and the base position of unaccusatives is easily identifiable. In addition, Russian offers evidence that constituents move to the left periphery of the clause, which allows us to compare the viability of freezing accounts. 
The rest of the paper is structured as follows. In section 2 we address the relevant properties of English, and present our experimental results on it. Sections 3 presents the relevant properties of Russian, and experimental results for that language. Section 4 discusses the experimental results in light of the main theoretical proposals sketched above. Section 5 outlines our conclusions and outstanding questions.

\section{English}

The goal of our study was to bring some clarity to the ongoing debate about whether subextraction out of different subject types in English is equally unacceptable. We have already indicated that researchers differ in their answer to this question. Without a consensus on the basic data, it makes sense to survey a large number of speakers to eliminate concerns of subjectivity, which is what the experiment below is designed to do. We will compare subextraction out of subjects of unaccusatives, unergatives, and transitives.

The distinction between unergatives and unaccusatives in English has been explored extensively (Levin and Rappaport Hovav 1995, Sorace 2000, a.o.), and unaccusativity diagnostics have been subject to serious scrutiny. For our purposes, it was sufficient to select a representative sample of verbs covering different positions of the unaccusativity hierarchy as proposed by Sorace (where different links correspond to the degree of "prototypical" unaccusativity): 
(5) verbs denoting change of location $>$ verbs denoting change of state $>$ verbs denoting continuation of state $>$ verbs denoting existence of state

\subsection{Experimental study of extraction out of subjects in English}

The main goal of the experiment was to test extractability from subject islands varying by the structural position of the subject. We collected native speakers' acceptability judgment data in an online task, which allowed us to establish the basic judgments for the relevant sentences. We also conducted an online self-paced reading task.

\subsubsection{Materials}

The two tasks shared the same set of materials. We used a $3 \times 2$ design crossing subextraction site [subject of unaccusative (SuUA), subject of unergative (SuUE), subject of transitive (SuTr)] with extraction type (subextraction, wh control).

There were 36 experimental items and 68 filler sentences. The fillers included a mixture of grammatical and ungrammatical sentences. Subjects answered comprehension questions after every three or four sentences.

To mask the difference between subject and object questions (with vacuous movement and regular movement, respectively), we embedded all our test sentences under matrix verbs such as wonder, ask, inquire, etc.

The examples below illustrate extraction out of SuUA (6), SuUE (7), and out of SuTr (8). All the examples were of equal length up to the postverbal constituent of the embedded clause; in order to make up for the absence of an object in intransitive clauses, 
and to avoid end-of-sentence wrap-up effects, we included adjunct PPs in all conditions. In the examples below, (a) represents target sentences and (b), baseline (control) clauses with the wh-word in subject position.

(6) SuUA

a. Janet wonders what [the conference on ___ lasted for a week

b. Janet wonders what kind of conference lasted for a week

(7) SuUE

a. Janet wonders what [the conference on ___ ] succeeded for a week

b. Janet wonders what kind of conference succeeded for a week

(8) $\mathrm{SuTr}$

a. Janet wonders what [the conference on __ ] ignored the proposals for a week

b. Janet wonders what kind of conference ignored the proposals for a week

The stimuli contained questions with what and with who at the ratio of 2 to 1 , because questions with what are more natural and allow for a broader range of complex DPs.

Another consideration in the design of our stimuli was the observation that extraction out of islands becomes more tolerable when the DP is less definite (Chung and McCloskey 1983; Kluender 1998). Compare the following examples, where the extraction out of an indefinite complex DP intuitively seems less anomalous: 
(9)
a. *This is the paper [that we need to find the linguist [that understands
]]
b. */?This is the paper [that we need to find a linguist [that understands _ ]]
c. ?This is the paper [that we need to find someone [who understands ]

In order to probe for the role of definiteness, we constructed our stimuli so that half of the subjects were definite and the other half were indefinite, equally distributed across the subtypes listed above. Each participant was presented with definite and indefinite stimuli.

\subsubsection{Subjects}

56 native English speakers participated in the reading time study. The subjects were all tested in the Boston area. All subjects were adults over 18 years of age. Of the 42 speakers whose age and gender data were collected, age ranged from 19 to 59 (average age 24, SD 7 years); 25 subjects were female. The subjects were reimbursed for their participation.

Participants were tested individually in a quiet room. Subjects completed the selfpaced reading task first. Sentences were presented using either $\mathrm{IBEX}^{2}$ or the Linger Software package (Rohde 2003) on a PC, with a high sensitivity keyboard in both setups. Participants pressed the space bar in order to continue reading each sentence, in a word-by-word fashion. One third of the sentences were followed by a yes-no comprehension question. Results from their accuracy data show that the average accuracy rate was $91 \%$, with every participant having an accuracy rate of at least $85 \%$. No subjects were excluded from the data analysis. In the judgment task, the instruction was to rate

\footnotetext{
2 http://spellout.net/ibexfarm (Alex Drummond, UMD)
} 
each sentence on a 1 to 7 scale, where 1 represented a completely unacceptable sentence, and 7 represented a fully acceptable one. The participants were asked to make the judgments based on their intuitions, rather than any prescriptive rules acquired in classroom settings. The task was set up in such a way as to allow us to record the subjects' judgments, as well as their reaction times.

\subsection{Results and discussion}

\subsubsection{Results: Judgment task}

Judgments (1-7; Likert-type scale) were transformed into z-scores, where means and standard deviations were estimated for each subject based on the responses across all target items. Z-judgments were analyzed in terms of a linear mixed effects model with random intercepts for subjects and items and random slopes (including correlations) for all fixed effects reported below grouped by subject and item. As there is currently no implementation for estimating the degrees of freedom of the $t$-statistic of the coefficients in linear mixed models with random slopes and correlations thereof, we report $\chi^{2}$ -

likelihood tests assessing whether a given fixed effect significantly improves data likelihood. Definiteness of the DP from which the subextraction took place and interactions of definiteness with transitivity and the unaccusative/unergative contrast do 
not contribute significantly to data likelihood $\left(\chi^{2}(3)=4, p=0.27\right)$. Definiteness is therefore omitted from all analyses reported below. ${ }^{3}$ The z-scores are shown in Figure 1.

\section{[figure 1 here]}

Figure 1. Judgments on baseline sentences and subject subextraction sentences in English, 1-7 scale.

There was a significant difference between judgments in the subextraction condition and the baseline $\left(\beta=-3.4, t=-14.6, \chi^{2}(1)=67.05, p<.0001\right)$; sentences in the baseline condition (mean $\left.=0.78, C I_{95}=[0.69 ; 0.87]\right)$ were judged about 1.6 standard deviations better than sentences in the subextraction condition (mean $\left.=-0.78, C I_{95}=[-0.72 ;-0.85]\right)$. There was no significant effect of transitivity $\left(\chi^{2}(1)=1.19, p=.28\right)$, but there was a marginal difference between the unaccusatives and unergatives $\left(\beta=-0.18, t=-1.68, \chi^{2}(1)=2.71, p<.1\right)$, with unaccusative subextraction being judged slightly higher. There were also no significant interactions between the contrast specifying extraction type and the other fixed effects $\left(\chi^{2}(2)=.74, p=.69\right)$.

3 The absence of definiteness effects is probably due to the size of the dependency; our dependencies are all very short. The results therefore give support to the idea that distance between the filler and gap affects the character of filler-gap relationships (see Bever and Sanz 1997: 86-88 on the role of distance in establishing filler-gap relationships). 


\subsubsection{Results: Self-paced reading task}

The results of the reading time task are presented in Figure 2. Recall that the stimuli had the following structure - here we omit any words past the first spillover region (W8 was a determiner in the transitive condition and a preposition in the intransitive condition):

\section{$\begin{array}{lllllllll}\text { W1 } & \text { W2 } & \text { W3 } & \text { W4 } & \text { W5 } & \text { W6 } & \text { extract'nsite } & \text { W7 } & \text { W8 }\end{array}$}

\section{[figure 2 here]}

Figure 2. Word-by-word reading times (raw RTs, ms) for baseline (control) sentences and for subextraction from the subject of an unaccusative, unergative, and transitive in English.

Reaction times more than 2 standard deviations greater or smaller than the mean reaction time for that word across all subjects and items were removed from the analysis. We analyzed raw $\log$-RT in terms of a linear mixed model with random intercepts for subjects and items and random slopes (including correlations) for all fixed effects reported below grouped by subject and item. We again report $\chi^{2}$-likelihood tests assessing whether a given fixed effect significantly improves data likelihood.

At word 7, right after the extraction site, we find a significant effect of verb transitivity $\left(\beta=-0.04, t=-2.02, \chi^{2}(1)=4.2, p<.05\right)$ in that word 7 is read slower in the transitive condition (mean $\left.=436.44 \mathrm{~ms}, C I_{95}=[397.44 ; 475.45]\right)$ than in the intransitive conditions (mean $\left.=405.51 \mathrm{~ms}, C I_{95}=[371.61,439.41]\right)$. There is no significant difference between 
unaccusatives and unergatives $\left(\beta=0.02, t=0.64, \chi^{2}(1)=0.4, p=.52\right)$. There is also no significant difference between subextraction and the baseline $\left(\beta=0.04, t=1.35, \chi^{2}(1)=1.62\right.$, $p=.2$ ). We further find no interactions between the contrast specifying the difference between subextraction and baseline and the other fixed effects $\left(\chi^{2}(2)=0.65, p=.72\right)$.

At word 8, the spillover, we again find a significant effect of transitivity $(\beta=-0.02, t=-$ 1.14, $\left.\chi^{2}(1)=5, p<.05\right)$; this word is read slower in the transitive condition (mean $\left.=375.40 \mathrm{~ms}, \quad C I_{95}=[350.75 ; 400.06]\right)$ than in the intransitive conditions (mean $\left.=368.48, C I_{95}=[345.2 ; 391.76]\right)$. At word 8 , there is also a significant difference between unaccusatives and unergatives $\left(\beta=0.05, t=2.19, \chi^{2}(1)=8.32, p<.005\right)$ in that word 8 was read faster in the unaccusative condition (mean $\left.=355.87, C I_{95}=[334.38 ; 377.35]\right)$ than in the unergative condition (mean $\left.=381.09, C I_{95}=[356.02 ; 406.17]\right)$. There is also a significant effect of extraction type $\left(\beta=0.11, t=5.47, \chi^{2}(1)=25.27, p<.0001\right)$ in that word 8 was read significantly faster in the baseline condition (mean $=350.54$, $\left.C I_{95}=[329.96 ; 371.13]\right)$ than in the subextraction condition (mean=391.04, $\left.C I_{95}=[364.15 ; 417.93]\right)$. Again, we find no interaction between the contrast specifying extraction type and the other fixed effects $\left(\chi^{2}(2)=2.4, p=.3\right)$.

Under the assumption shared by most researchers that reading time slowdowns are a reflection of processing difficulty, the reading times confirm that extraction out of subjects imposes a processing cost not seen in the baseline. Furthermore, the reading times allow us establish the following hierarchy of subextraction, from the most transparent (unaccusative subjects) to the most opaque (transitive subjects): 
(11) $\mathrm{SuUA}>\mathrm{SuUE}>\mathrm{SuTr}$

\subsubsection{Discussion}

The ratings of subextractions in the judgment task were quite low, a sign that the readers showed significant discomfort with extraction out of subjects, thus supporting the overall conception that even examples like (1) and (2a) are marginal at best. However, the marginal difference between unaccusative and unergative subjects in the judgment task and the results of the reading study show that not all subject islands behave the same way.

Unaccusative subject advantage. We find that extraction out of an unaccusative subject is not as pernicious as extraction out of an unergative or transitive subject. This result is consistent with the intuitions reported by some researchers, as discussed above. It is also consistent with the findings of earlier experimental studies (e.g., Hiramatsu 1999, 2000) that limited subject island stimuli to subjects of unaccusatives and found those islands to be weak. This result, however, is barely visible in our judgment task. ${ }^{4}$ Why? We would like to offer two considerations, one related to the grammar of English, the other more general.

In English clauses without an expletive subject, the subject of unaccusatives clearly has to move from its base position (internal argument) to the derived subject position. Unaccusative subjects remain relatively transparent (based on the reading data), and this

4 As we already mentioned, there is a mild effect in the judgment task favoring the subject of unaccusatives. 
result lends support to the idea that extraction targets the base position of a constituent, not its derived position (similar to Merchant 2001).

However, the subject of an unaccusative is inferior to the object in terms of subextraction - intuitions converge on the fact that objects are transparent for extraction, cf. $(2 a, b)$ above. So while the base position is a strong contender for the explanation of the results, it only goes halfway. The fact that the unaccusative subject is judged bad under subextraction suggests that its movement to the true subject position for Case affects its transparency.

Above, we introduced three different conceptions of freezing. The subject position in English is not an A-bar position, which rules out criterial freezing (3b); furthermore, subextraction is supposed to be possible under criterial freezing. The English data thus argue in favor of Case-related freezing, possibly along the lines of (3c) above. All the subject constituents, regardless of the verb type, are frozen since they have moved to spec, TP to receive Case. ${ }^{5,6}$

5 It is possible that judgments are sensitive to the derivational history of a given structure, although at this stage of our syntax-processing theories we do not yet have good tools to incorporate such "derivational memory" into processing. In the absence of such a mechanism, the judgment data favor the conclusion that English subjects are all frozen for extraction due to movement for Case.

${ }^{6}$ There is another, theoretically less interesting possibility: It could be the case that subextraction, when compared to the other sentences used in the experiment, is so 
Let us now turn to the variation in the acceptability of subextraction from unaccusative subjects reported in the literature. Some researchers accept unaccusative subject subextraction, but the average rating for all subject island violations here is rather poor. Why could that be? The explanation may have to do with the relative weight of the two factors that influence islandhood, viz., the base position of a constituent and freezing. Arguably, some English speakers are more sensitive to base position, and they find extraction out of unaccusative subjects tolerable, while other speakers are swayed by the fact that the subject has moved and treat it as frozen for further movement. This would explain the variation in judgments reported in the literature, with some researchers assigning more value to the base position, hence accepting sentences like (1a) and (2a), and others being more sensitive to freezing. But why would the latter group be in the majority, as our judgment results suggest? In our view, this has to do with the fact that in English the base position of the unaccusative subject is obscured because the subject has to move (unless the sentence has an overt expletive, which we did not consider in the experiment). ${ }^{7}$ A language where one could compare the extraction out of a base position to the extraction out of a moved position would be useful at this point, and this is exactly

exceedingly unnatural that relative orderings of different types of subextraction become indiscernible.

7 Extraction out of the unmoved internal argument of an existential is predictably fine:

(i) Which wars were there documentaries about at the festival?

(ii) The tragedies that there have been essays about are all but forgotten. 
what we will be examining in Russian. Our prediction is that in languages where the base position is "visible" on the surface the difference among subtypes of subject islands would be more pronounced. Furthermore, since Russian subjects move to spec,TP for reasons other than Case, we do not expect them to show freezing effects.

The other consideration we would like to offer is more general. It has to do with the interpretation of different methods of experimental testing. In assessing primary data, linguists rely on native speakers" intuitions: a structure can be judged "good," "bad," or in between, although the true meaning of these labels is elusive. Judgment tasks are just another way of obtaining native speaker intuitions, albeit on a more massive scale (Sprouse \& Almeida 2010). In comparing judgment data to behavioral measures, such as reading time, we make an assumption that these measures should be parallel. But this is just an assumption. Do reading times really allow us to get at the root of acceptability judgments? When judgments and reading times pattern together, one can simply assume that acceptability and ease of reading work in sync and even push it as an explanation. In our study, however, the judgment data are less fine-grained than the reading time data. We thus conclude that both tasks elicit data which reflect the tension between the base position and the frozen position, and that this is more visible in the reading time task. However, the power of this conclusion crucially relies on the assumption that reading time tasks reflect the same language evaluation processes as judgment tasks, and this assumption needs to be scrutinized further.

Transitivity penalty. In addition to finding that subjects of unaccusatives are weaker islands than other subjects, we find a pronounced effect of transitivity - we will refer to it 
as a transitivity penalty. Transitive sentences showed a slowdown at the embedded verb in the baseline condition, where there were no differences other than the valency of the verb. Transitive subjects also caused a heavier processing load in the reading study than both unaccusatives and unergatives. Since unergative subjects are also external arguments, the external argument effect cannot be implicated. This result suggests that verbal valency or argument structure has an effect on the processing of syntactic structure. Furthermore, it adds important empirical evidence in support of the psychological reality of the argument/adjunct distinction: our intransitive stimuli had PP adjuncts to balance the surface length but these adjuncts appear to impose a smaller processing penalty than arguments of a transitive clause.

At this point, we would like to characterize the transitivity penalty only as an emergent empirical generalization. It needs to be investigated further across different structures within and across languages. For instance, it is not yet clear if the difference we find is due to transitivity (the presence of a complement) or to the presence of any extra argument as opposed to an adjunct; these two possibilities make different predictions for psych verbs. These predicates are a fruitful avenue for future research; psych verbs have two arguments, but are not transitive, so their investigation would allow us to distinguish between the effect of valency and the effect of transitivity.

In sum, the relative weakness of unaccusative subject islands can be accounted for if we assume that extraction targets the base position of the extraction site: unaccusative subjects start out as internal arguments. This effect in English is weak, and we hypothesize that it is canceled out by the subject's movement to obtain Case, which leads 
to freezing. The difference between the base and derived position is easier to assess in a language that has freer word order than English.

\section{Russian}

\subsection{Russian clause structure}

Due to rampant scrambling, the subject position and the highest left peripheral specifier position are not necessarily one and the same in Russian. Overall, the language

is SVO; this means that the subject occurs in the left peripheral specifier position, but other XP's can also occur in that position. ${ }^{8}$

In formal studies of Russian, there is no common view on how the structure above VP is derived. Given the lack of consensus, we assume the minimal structure needed and do not commit to any positions above the TP and simple CP. As far as verb movement is concerned, it is generally held that such movement is short, to a projection below $\mathrm{T}$, most likely to an aspectual head (Bailyn 1995, Junghanns and Zybatow 1997, Babko-Malaya 2003, Gribanova 2010). For transitive verbs, we assume the basic structure in (12).

8 Some researchers, for example King 1995, posit a number of left peripheral positions above the Russian subject. We will return to this issue below. 
(12)

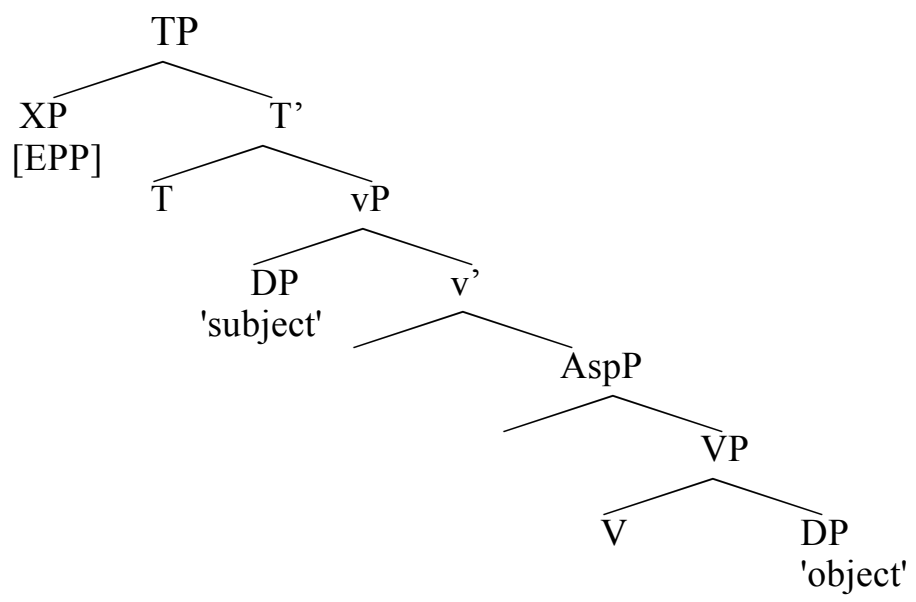

It is generally assumed that Case is licensed in Russian via Agree (see Kallestinova 2007 for an overview). Subjects can move to spec,TP to satisfy the EPP, resulting in the SVO word order (Baylin 2004). On the surface, both subjects and objects can precede or follow the verb. With respect to the object, it is safe to assume that its base position is postverbal and that it scrambles out of the VP into the vP area (13b). ${ }^{9}$

(13) a. [тр naša sosedka [vp naša sosedka [vp prinesla pirogi]]] [our neighbor].NOM brought cakes.ACC

b. [Tр naša sosedka [vр [vp pirogi [vp prinesla piregi]] [our neighbor].NOM cakes.ACC brought

c. [тр pirogi [Aspp prinesla [vp naša sosedka [vp prinesla pirogi] cakes.ACC brought [our neighbor].NOM 'Our neighbor brought cakes.'

9 VP or vP remnants also can move after one of the arguments has moved. 
The derivation of (13c) is less straightforward (see also Bailyn 2004 and Kallestinova 2007 for discussion). There are three issues here. The first concerns the position of the verb. Most researchers agree that the verb moves to a higher projection (with some disagreement regarding the actual landing site).

The second issue has to do with the position of the subject. One could imagine that the subject is scrambled to the right, for example via extraposition. ${ }^{10}$ On that option, the subject is essentially a high adjunct. This predicts that it should be a strict island for extraction - but it is not, as much of our discussion below shows (see also Stepanov 2001, 2007 for primary data). In addition, one would expect the extraposed constituent to take wide scope (cf. Fox and Nissenbaum 1999), however, this is not the case, cf. (14a, b), where the latter example is a putative case of extraposition:

(14) a. č́i-to deti vse vremja vorujut moi konfety someone's children always steal my candy 'Someone's children always steal my candy.'

ALWAYS $>$ SOMEONE, SOMEONE $>$ ALWAYS

b. moi konfety vse vremja vorujut č́i-to deti my candy always steal someone's children 'Sm'one's children always steal my candy.'

$$
\text { ALWAYS }>\text { SOMEONE, * SOMEONE }>\text { ALWAYS }
$$

${ }^{10}$ Both of these possibilities could be ruled out with Kayneian minimalist assumptions, but we would like to consider empirical arguments against them as well. 
Based on this, we conclude that the order in (13c) represents the base position of the subject in spec,vP; it is an A-position.

The final issue has to do with the position of the object: presumably it moves to TP (not higher, because this position is available in embedded clauses - cf. King 1995, Bailyn 1995), as is shown in our representation in (13c). Alternatively, the object could left adjoin to TP, in some kind of a topic position (King 1995). We will return to this issue in the discussion of our experimental results.

Unlike English, Russian allows us use diagnostics to separate unaccusative and unergative predicates with a high degree of certainty (cf. the genitive of negation, Babyonyshev et al. 2001; Potsdam and Polinsky 2011; Polinsky and Potsdam 2012). ${ }^{11}$ The structures for these predicates are shown in (15) and (16), with irrelevant details omitted. For unaccusatives, we follow the uncontroversial assumption that the subject originates in the VP and then moves to a higher position.

(15) Unergatives: $\quad[\mathrm{TP}$ XP [vP Subject [vP ]]]

(16) Unaccusatives: [TP XP [vP Subject ]]

In our experimental design we used pre- and post-verbal constituents, schematized in (13a) and (13c). Before we describe our experimental sentences, we need to introduce the 11 Another unaccusativity test proposed for Russian is based on the distributive phrase with po, limited to subjects of unaccusatives and direct objects, but not the other subject types (Babby 1980, Pesetsky 1982, a.o.). However, this diagnostic has met with a number of counterexamples (see Harves 2002, 2003). 
phenomenon of long-distance scrambling that we relied on experimentally. Russian has long-distance A-bar movement (Bailyn 1995, 2001), which allows the scrambling of arguments and some adjuncts (Bailyn 2001, Shields 2005, Testelets 2006) over the subjunctive complementizer čtoby: ${ }^{12}$

(17) a. oni kupili mašin-u v Moskve they bought car-ACC in Moscow 'They bought a car in Moscow.'

b. ja mašin-u xotel [čtoby oni kupili___ v Moskve] 1SG car-ACC wanted COMP.SUBJN they bought in Moscow 'I wanted them to buy a car in Moscow.'

c. čto ty xotel [čtoby oni kupili__ $\mathrm{v}$ Moskve]? what 2SG wanted COMP.SUBJN they bought in Moscow 'What did you want them to buy in Moscow?'

Long-distance wh-movement is not acceptable for subjects, at least under normal intonation (Bailyn 2001, 2003, 2004, Testelets 2006, Glushan 2006), but is possible for extraction out of subjects, in an apparent instance of left branch extraction. In the stimuli below, we will be using subextraction out of embedded subjects and objects with the whword appearing over the subjunctive complementizer.

12 This scrambling is typical of more colloquial registers. Scrambling over the overt or silent indicative complementizer čto is subject to more variation across speakers, which is why we chose not to use it in this study. 


\subsection{Experimental study of extraction out of subjects in Russian}

The main goal of the experiment was to test extraction out of DPs (left branch extraction), varying the structural position of the subject and object. We collected native speakers' acceptability judgment data in an online task. The procedure was the same as described for English; the only difference was that we used a 1-5 scale for the judgment task.

\subsubsection{Materials}

We used a 4 × 2 × 2 design based on the following independent variables: subextraction site [subject of unaccusative (SuUA), subject of unergative (SuUE), subject of transitive $(\mathrm{SuTr})$, object $(\mathrm{OBJ})]$; extraction type (subextraction vs. grammatical control whquestions); pre-/postverbal position of the subextraction site.

In total there were 40 experimental items and, in two versions of the experiment that differed only in the number and type of fillers, either 142 or 107 filler sentences (there were no differences between these two in terms of the observed results). The fillers included a mixture of grammatical and ungrammatical sentences. Subjects answered comprehension questions after every three or four sentences.

The examples below illustrate extraction out of SuUA (18), SuUE (19), $\operatorname{SuTr}(20)$, and out of OBJ (21), with the extraction site shown preverbally. ${ }^{13}$

13 All the examples were of equal length; in order to make up for the absence of an object in intransitive clauses, we included adjunct PPs or adverbs. 
(18)

kakie ty mečtaeš' [čtoby __ aktjory okazalis' na scene]? what-kind-of 2SG dream.PRES.2SG COMP actors appeared on stage 'What kind of actors do you hope to appear on the stage?' (SuUA)

(19) kakie ty mečtaeš' [čtoby _gruppy tancevalina scene]? what-kind-of 2SG dream.PRES.2SG COMP groups danced on stage 'What kind of groups do you hope to dance on the stage?' (SuUE)

(20) kakie on prosil [čtoby __sotrudniki blagodarili direktora]? what-kind-of he asked COMP employees thanked director 'What kind of staff members did he ask to thank the director?' (SuTr) kakie ty xočešs [čtoby _otmetki ob"javil professor]? what-kind-of 2SG want COMP grades announced professor 'What kind of grades do you want the professor to announce?' (OBJ)

Russian has different case marking depending on the animacy of the object. The initial form of the wh-word is kakogo/kakuju/kakix for animates in the singular masculine, singular feminine, and plural respectively; for inanimate plural objects it is invariably kakie, indistinguishable from the nominative used with animates and inanimates. Thus, we only tested extraction out of inanimate objects, otherwise the reader could immediately predict that the question was about an animate object, not subject. For the subjects, the stimuli included a roughly even ratio of animate to inanimate DPs in the subject position. The stimuli were normed by five native speakers.

\subsubsection{Participants}


A total of 147 native Russian speakers participated in the study. 21 speakers were tested in the Boston area, 23 in Moscow, and 103 speakers in an online study with participants in Estonia, Ukraine, Canada, USA, Australia, and Holland. All subjects were adults over 18 years of age. Of the 99 speakers whose age data were collected, ages ranged from 19 to 67 years (average age 30, SD 9 years). Of the 121 speakers whose gender data were collected, 76 were females and 45 were males. Those participants who were tested in the US had been outside Russia for an average of 1.5 years. Results from the accuracy data show that the average accuracy rate was $91 \%$, with every participant having an accuracy rate of at least $85 \%$. No one was excluded from the data analysis.

\subsubsection{Results}

The results for subextractions are summarized in Figures 3 and 4, with two word orders (VX and $\mathrm{XV}$ ) shown separately and treated as two different experiments. Responses to control questions were not analyzed.

Judgments (1-5; Likert-type scale) were transformed into z-scores, where means and standard deviations were estimated for each subject based on the responses across all target items (unaccusatives, unergatives, transitive subjects, objects). z-judgments were analyzed in terms of a linear mixed effects model with random intercepts for subjects and items and random slopes (including correlations) for all fixed effects reported below grouped by subject and item. We again report significances based on model comparison $\left(\chi^{2}\right.$-likelihood test). 
In the VX order, there is a significant difference between transitive and intransitive sentences $\left(\beta=-0.4, t=-3.2, \chi^{2}(1)=9.85, p<.005\right)$; transitive (mean=-0.16, $C I_{95}=[-0.25$;0.07]) sentences are judged worse than intransitive (mean $=0.17, C I_{95}=[0.07 ; 0.26]$ ) sentences. We further find a significant difference between unaccusative and unergative $\left(\beta=-0.36, \quad \mathrm{t}=-2.03, \quad \chi^{2}(1)=3.88, \quad p<.05\right) \quad$ subjects; extraction out of unaccusatives (mean $=0.33$,CI_95 $=[0.22 ; 0.43])$ is judged better than out of unergatives (mean $=0.0$, $\left.C I_{95}=[-0.09 ; 0.09]\right)$. Finally, we find a significant difference between extraction out of objects and extraction out of transitive subjects $\left(\beta=0.75, t=4, \chi^{2}=10.93, p<0.001\right)$; transitive subjects (mean $=-0.49, C I_{95}=[-0.59 ;-0.40]$ ) are judged as less transparent than objects $\left(\right.$ mean $\left.=0.17, C I_{95}=[0.08 ; 0.26]\right)$.

In the $\mathrm{XV}$ order, there is again a significant difference between transitive and intransitive sentences $\left(\beta=-0.39, t=-3.77, \chi^{2}(1)=12.32, p<0.0005\right)$, in that transitive sentences (mean=-0.16, $\left.C I_{95}=[-0.25 ;-0.07]\right)$ are judged worse than intransitive sentences (mean $=0.16$,CI $95=[0.06 ; 0.26])$. We also find a marginally significant difference between unaccusatives and unergatives $\left(\beta=-0.22, \mathrm{t}=-1.73, \chi^{2}(1)=2.98, p<.01\right)$ in that extraction out of unaccusative subjects (mean=0.29, $C I_{95}=[.19 ; .4]$ ) is judged better than extraction out of unergative subjects (mean $\left.=0.03, C I_{95}=[-0.07 ; 0.13]\right)$. Finally, we find a significant difference between the extraction out of objects vs. transitive subjects ( $\beta=0.4$, $\left.t=4, \chi^{2}=5.83, p<0.05\right)$ in that subjects (mean=-0.31, $\left.C 195=[-0.41 ; 0.23]\right)$ are less transparent for subextraction than objects (mean $\left.=0.0, C_{95}=[-0.1 ; 0.1]\right)$.

\section{[figure 3 here] [figure 4 here]}


Figure 3. Judgments on Russian subextraction, VX

Figure 4. Judgments on Russian subextraction, XV

In sum, across both word orders there is a robust difference between transitive subjects (judged the lowest) and all the other constituents. There is also a significant effect of grammatical function, objects being rated higher than subjects. Within intransitives, there is a significant effect of unaccusativity - extraction out of unaccusative subjects was rated higher than extraction out of subjects of unergatives and even out of objects.

Thus, extraction out of subjects in Russian follows the cline in (22):

(22) SuUA $>$ SuUE $>$ SuTr

Note also that the scores for all the three subject types are roughly the same in the VX and XV orders; however, there is a significant deterioration in judgments of subextraction out of the direct object in the preverbal position. ${ }^{14}$ If we now add the object to the mix, the Russian results suggest the following patterns with respect to transparency for subextraction:

\section{Transparency for subextraction}

${ }^{14}$ We also conducted a self-paced reading pilot study which produced results consistent with the patterns of judgments observed in terms of relative ordering of empirical means (significance was not assessed). For brevity, we will not go into the details of this study here. 


\begin{tabular}{|l|l|l|l|l|}
\hline & SuUA & Obj & SuUE & SuTr \\
\hline XV order & Transparent & Island & Island & Island \\
\hline VX order & Transparent & Transparent & Island & Island \\
\hline
\end{tabular}

\subsubsection{Discussion}

The Russian experiment shows that not all subject islands are created equal, with unaccusative subjects being the most transparent. Thus, Russian, much more clearly than English, shows the unaccusative subject advantage: subjects of unaccusatives are weaker islands than their external argument counterparts. This lends support to the empirical conclusion that subject island properties co-vary with the structural type of the predicate.

When the subject appears postverbally, it is presumably in its base position. Postverbal objects and unaccusative subjects exhibit equivalent reading times, shorter than the reading times for extraction out of unergative and transitive subjects. All four types of constituents are in their base position (see the structures above), but only objects and unaccusative subjects are internal arguments. Thus, the contrast between unergative and transitive subjects on the one hand, and unaccusative subjects and objects on the other, suggests that the familiar difference between external and internal arguments is critical for extractability.

Since Russian has a more flexible word order than English, it allows us to better dissociate the effects of base position from the hypothetical (and varied) effects of freezing. By hypothesis, all the preverbal constituents appear in spec,TP, which in Russian is an A-position. This movement should result in freezing under the generalized conception of freezing (3a). 
However, the subjects of all three types seem unaffected by freezing: We find the very same ordering of extraction in the analyses of XV and VX judgments, suggesting that the two word orders pattern alike. This argues against generalized freezing, according to which any movement leads to opacity. The two other approaches to freezing do not predict any island effects. Criterial freezing (3b) does not apply to A-positions and does not rule out subextraction (Rizzi 2007). Case-related freezing (3c) should not apply because Case in Russian is assigned via Agree and there is no movement for Case. Thus, the Russian facts argue against the generalized approach to freezing but do not distinguish between the two other conceptions of freezing which predict equally well the empirical effects we found in Russian.

We are left with one outstanding issue: the opacity of preverbal objects, reflected in the ratings for $\mathrm{XV}$ word order and in the reading time pilot study. There are three possibilities here and we will consider each in turn.

The simplest explanation could come from frequency effects: if the OVS word order was rare in Russian, it could be expected to independently cause significant discomfort for speakers. However, this suggestion is untenable. SVO and OVS are the two most common Russian word orders, with OVS occurring about $21 \%$ of the time (Kallestinova 2007: 51). In our search of the Russian National Corpus, we found 95 OVS sentences out of 244 clauses embedded under the conjunction čtoby.

The second explanation could rely on the dual nature of spec,TP, the idea being that nominative arguments checking the EPP show A-properties, and non-nominative arguments show A-bar properties. Proposals appealing to the dual A/A-bar nature of 
spec,TP have been advanced for West Flemish and Italian (Haegeman 1995), Spanish (Goodall 2001, 2002), and Russian (Borovikoff 2001). All these proposals share a distinction between nominative arguments, which have A-properties, and non-nominative constituents, which have A-bar properties. However, even if this reasoning is correct, it would require, as the next step, appeal to criterial freezing ((3b) above): the object has moved to spec, TP, an A-bar position, presumably satisfying the Topic criterion. But as we have already mentioned, criterial freezing does not rule out subextraction, so unless the constraints on subextraction are radically revised, this move does not help explain the resulting opacity of the object.

We are then left with the third possibility, the one we mentioned in passing in our discussion of the OVS derivation (13c) above. The proposal is that the object is actually not in spec,TP, but instead is left adjoined to TP (Junghanns and Zybatow 1997, King 1995), thus: ${ }^{15}$

(24) [тр Object [тр ec [T Verb [vP Subject [vP Verb Object]]]]

Adjuncts are strong islands, and the adjunction will therefore explain why the object is no longer transparent in the preverbal position. This explanation receives additional support from scope readings. Both preverbal and postverbal subjects in Russian are scopally ambiguous, as illustrated by the following example:

15 We leave open the question of whether the object is base generated in this position or moves into it; for our purposes, these options make no difference. 
(25) a. vse studenty ne sdali domašnie zadanija [all students].NOM not gave homework.PL.ACC

b. ne sdali vse studenty domašnie zadanija not gave [all students].NOM homework.PL.ACC 'All students did not turn in their homework.' $\quad$ ALL $>$ NEG, NEG $>$ ALL Similarly, postverbal objects are scopally ambiguous:

(26) Maša ne priglasila vsex studentov Masha not invited [all students].ACC 'Masha did not invite all students.' $\quad$ ALL > NEG, NEG > ALL Preverbal objects, however, take only wide scope:

(27) vsex studentov Maša ne priglasila [all students].ACC Masha not invited 'Masha did not invite all the students.' $\quad$ ALL $>$ NEG, *NEG $>$ ALL

Such a scopal restriction is unexpected if the object lands in spec, TP, the same position as the subject. It is, however, compatible with the status of the object as a high adjunct (cf. also (14) above, where the same effects are observed). We conclude that the preverbal object is in a left-adjoined position at TP (cf. King 1995 for a similar proposal), and this structural position accounts for its opacity. 


\section{General discussion}

We started by asking the following research questions: Are all subject islands equally opaque? If not, does the strength of the island depend on its base position or on the derived position of the subject?

The answer to the first question is a clear "no". We were able to show, both on the basis of judgments and reading times, that subjects of unaccusatives are sufficiently transparent. This effect is consistent with informal observations on subjects of unaccusatives in English, as well as with experimental studies that showed that unaccusative subjects are weak islands (Hiramatsu 1999, 2000 for English). The overall conclusion is that not all subject islands are equally impermeable to movement. Thus, the subtle intuitions that have been showing up here and there (all the while being questioned by other native speakers) have been confirmed by quantitative study. Even if our interpretation of the reasons for subject island variability is not on the right track, we hope to have demonstrated that unaccusative subjects are more transparent than the other types of subjects in English or Russian.

The relative transparency of unaccusative subjects observed in our data gives support to the conception that extraction targets the base position of a constituent (cf. Merchant 2001, Jurka 2010 and references therein). The reason unaccusative subjects are permeable is that they start out as internal arguments (complements to the verb), and these complements are transparent to extraction.

We have also entertained an alternative to the base position analysis, namely, the possibility that subjects are islands because of freezing effects: once a constituent has 
moved to a particular position, it is no longer transparent to (sub)extraction. We find that generalized freezing, as applied to any moved constituent, cannot account for the English and Russian data discussed above. The English data lend support to the more narrow, Case-based conception of freezing (Lohndal 2011): constituents moving for Case are subsequently frozen. English and Russian present a helpful contrast here: in English, but not in Russian, movement happens for Case reasons and leads to freezing. Russian subjects are judged about the same both postverbally (in their base position) and preverbally (moved).

Although one has to be cautious comparing experimental data across languages, English unaccusative subjects appear to be stronger islands than their Russian counterparts. We suggested that the English results could be accounted for by a combination of two principles: that extraction targets the base position of a constituent, and that Case movement induces freezing. Our judgment task results seem to reflect the effects of freezing more than the effects of the base position, but other researchers (for example, Hiramatsu 1999, 2000) found unaccusative subjects to be quite transparent. Our reading time results also support this transparency. We attribute the variation in judgments on extraction out of English unaccusative subjects to two conflicting pressures: base position transparency and Case-induced freezing.

Turning to Russian, the contrast between unaccusative subjects and the other subject types was even sharper. We attribute that to two factors: Russian word order distinguishes between the base and derived position, and Russian DPs receive Case via Agree. Thus, there is no Case-related freezing and there is a clear-cut distinction between 
external and internal arguments. As internal arguments, Russian unaccusative subjects and objects are extremely similar in terms of subextraction. Somewhat unexpectedly, preverbal objects in Russian show great opacity. In keeping with some theoretical proposals in Russian syntax, we hypothesize that this is due to their adjunct status; they are adjoined at TP and as adjuncts show strong island effects.

Our results also show that transitive subjects are the strongest subject islands. A similar result has been found in Czech (Sturgeon et al. 2010) and German (Jurka 2010). It is hard to imagine how the strength of SuTr islands can be explained in purely syntactic terms: both SuUE and SuTr are merged as external arguments, presumably at the same height, and both move to the same higher specifier.

Thus, we need to look for a different explanation. We hypothesize that a profitable path to consider is the argument structure of these verbs. When a parser encounters a transitive verb, it needs to project two arguments, not just one, as is the case with intransitives; that may impose an additional burden on the processing of such clauses. At this stage, this is just a hypothesis and needs to be tested by considering other two-place verbs that are not syntactically transitive. Such verbs would allow us to understand whether what matters is the actual presence of a complement (a syntactic representation) or the availability of an argument structure with two or more participants.

There is growing evidence that valency makes the processing of long-distance dependencies more difficult. Jurka (2010) found a transitivity effect in German similar to the one reported here. Researchers have noticed that transitivity imposes an additional cost on the processing of long-distance dependencies by children (Goodluck and 
Tavakolian 1982; Guasti 2002: 226; Diessel 2009, a.o.) and adults (O’Bryan 2003, Friedmann et al. 2008, Polinsky et al. 2011, a.o.). For English, Chen et al. (2005:161) suggests that there may be storage cost associated with predicting arguments of verbs in the region following the verb. In particular, Chen et al. compared reading times for the object NP in the obligatory transitive condition and the obligatory ditransitive condition. They found faster reading times for the object of a transitive. As for the explanation of the transitivity penalty, it could either be related to storage costs (per Chen et al. 2005), or point to a direct mapping between event structure and processing (as suggested in O'Bryan 2003). It could also be due to yet unconsidered factors. We believe it is too early to explain this transitivity penalty because we still need to find out where exactly it applies. Subject islands seem to be just another case where it is implicated, but the full range of application of the penalty is not yet known.

\section{Conclusions}

This paper analyzed subject islands in English and Russian. The choice of subject islands was motivated by the fact that the primary literature vacillates between treating them as weak or strong. As for the languages of study, we chose English because it has been at the core of numerous discussions concerning the islandhood of subjects, and Russian because it is ideally suited to test the two main hypotheses concerning island effects: the role of the base position of a constituent, which the word order makes directly visible, and the role of freezing, which becomes relevant when subject constituents move 
to spec,TP. In other words, Russian fills in the empirical gaps left open by the rigid surface order of English.

Our results show that subject islands vary in strength depending on the type of the predicate, with unaccusative subjects being the weakest islands because of their initial status as internal arguments. This in turn validates the idea that extraction is sensitive to the base position of the constituent from which it moved. This is particularly evident in Russian, where subextraction out of unaccusative subjects and postverbal objects is equally acceptable.

In English, however, unaccusative subjects are less transparent than objects; we attribute this difference to the fact that English speakers have to deal with the tension between the permissible extraction out of a base position and the impossible extraction out of a constituent that is frozen, due to Case-related movement. This tension can also explain disparities in the acceptability of unaccusative subject islands reported in the literature. While we have not been able to find solid support for the more general freezing accounts of islands, we can offer new evidence in support of a more specialized, Caserelated conception of freezing as proposed by Lohndal (2011).

Looking at our results from a broader perspective that connects grammar and processing, we would like to conclude with a puzzle. Multiple processing studies have established that long-distance dependencies involving subject gaps are easier to process than object-gap dependencies. But subextraction out of subjects and objects is just the opposite: objects are much more transparent to subextraction, and only those subjects that are in some way like objects exhibit some transparency. The Russian data also suggest 
that the more an object resembles a subject (e.g., in the OVS word order), the less transparent it becomes. Thus, preferences in extraction and subextraction are mirror images of each other. One could certainly state that extraction and subextraction are completely different, but from the processing standpoint, both establish a long-distance dependency, which means that they have an important thing in common. If so, it would be worthwhile to at least explore accounts that connect them and explain the mirror image that we observe. We leave that to the proverbial future research.

\section{References}

Babko-Malaya, O. 2003. Perfectivity and prefixation in Russian. Journal of Slavic Linguistics 11, 5-36.

Babyonyshev, M., J. Ganger, D. Pesetsky, and K. Wexler. 2001. The maturation of grammatical principles: Evidence from Russian unaccusatives. Linguistic Inquiry 32, 1-43.

Bailyn, J. 1995. Underlying phrase structure and short verb movement in Russian. Journal of Slavic Linguistics 3, 13-58.

Bailyn, J. 2001. On scrambling: A reply to Bošković and Takahashi. Linguistic Inquiry 32, 635658.

Bailyn, J. 2002. Inversion, dislocation and optionality in Russian. In G. Zybatov, U. Junghanns, G. Mehlhorn and L. Szucsich (eds.). Current Issues in Formal Slavic Linguistics (FDSL 3), 280-293. Frankfurt/Main: Peter Lang.

Bailyn, J. 2003. Does Russian scrambling exist? In S. Karimi (ed.). Word order and scrambling, 156-176. Oxford: Blackwell.

Bailyn, J. 2004. Generalized Inversion. Natural Language and Linguistic Theory 22, 1-49. 
Bailyn, J. 2007. A derivational approach to micro-variation in Slavic binding. In R. Compton, M. Goledzinowska, and U. Savchenko (eds.). Annual Workshop on Formal Approaches to Slavic Linguistics 15, 25-41. Ann Arbor: Michigan Slavic Publications.

Bever, T., and M. Sanz. 1997. Empty categories access their antecedents during comprehension: Unaccusatives in Spanish. Linguistic Inquiry 28, 69-91.

Boeckx, C. 2008. Bare syntax. Oxford: Oxford University Press.

Borovikoff, N. 2001. Unaccusativity and movement in Russian: Integrating formal syntax and discourse functions. Ph.D. Dissertation, Indiana University.

Braze, F. 2002. Grammaticality, acceptability, and sentence processing: A psycholinguistic study. Ph.D. Dissertation, University of Connecticut.

Chomsky, N. 1986. Barriers. Cambridge, MA: MIT Press.

Chomsky, N. 1991. Some notes on the economy of derivation and representation. In R. Freidin (ed.), Principles and Parameters in Comparative Grammar, 417-54. Cambridge, MA: MIT Press.

Chomsky, N. 2008. On phases. In R. Freidin, C. P. Otero, and M.-L. Zubizarreta (eds.), Foundational issues in linguistics, 133-166. Cambridge, MA: MIT Press.

Chvany, K. 1975. On the Syntax of BE-Sentences in Russian. Bloomington: Slavica.

Cinque, G. 1990. Types of $A^{\prime}$-Dependencies. Cambridge, MA: MIT Press.

Chung, S. and J. McCloskey. 1983. On the interpretation of certain island effects in GPSG. Linguistic Inquiry 14, 704-713.

Culicover, P. and K. Wexler. 1981. Formal principles of language acquisition. Cambridge, MA: MIT Press.

den Ouden, D.-B., S.Fix, T.Parrish, and C. Thompson. 2009. Argument structure effects in action verb naming in static and dynamic conditions. Journal of Neurolinguistics 22, 196-215. 
Diessel, H. 2009. The emergence of relative clauses in early child language. MS. University of Jena.

Fox, D. and J. Nissenbaum. 1999. Extraposition and scope: a case for overt QR. In S. Bird, A. Carnie, J. D. Haugen, and P. Norquest (eds.), Proceedings of the $18^{\text {th }}$ West Coast Conference on Formal Linguistics, 25-36. Sommerville, MA: Cascadilla Press.

Francom, J. 2009. Experimental syntax: Exploring the effect of repeated exposure to anomalous syntactic structure - evidence from rating and reading tasks. Ph.D. Dissertation, University of Arizona.

Friedmann, N., G. Taranto, L. Shapiro, and D. Swinney. 2008. The leaf fell (the leaf): The online processing of unaccusatives. Linguistic Inquiry 39, 355-377.

Glushan, Zhanna. 2006. Japanese style scrambling in Russian: Myth and reality. Master's thesis, University of Tromsoe.

Goodall, G. 2001. The EPP in Spanish. In. W. Davies and S. Dubinsky (eds.), Objects and other subjects: Grammatical functions, functional categories, and configurationality, 193-223. Dordrecht: Kluwer.

Goodall, G. 2002. On preverbal subjects in Spanish. In T. Satterfield, C. Tortora, and D. Cresti (eds.), Current issues in Romance languages: Selected papers from the 29th Linguistic Symposium on Romance languages, 95-109. Amsterdam: John Benjamins.

Goodall, G. 2004. On the syntax and processing of wh-questions in Spanish. In B. Schmeiser, V. Chand, A. Kelleher, and A. Rodriguez (eds.) Proceedings of the $23^{\text {rd }}$ West Coast Conference on Formal Linguistics, 101-114. Somerville, MA: Cascadilla Press.

Goodluck, H., and S. L. Tavakolian. 1982. Competence and processing in children's grammar of relative clauses. Cognition 11, 1-27. 
Grewendorf, G., and J. Kremers. 2009. Phases and cycles: Some problems with Phase Theory. The Linguistic Review 26, 385-430.

Gribanova, V. 2010. Composition and locality: The morphosyntax and phonology of the Russian verb complex. Ph.D. Dissertation, UC Santa Cruz.

Guasti, M.T. 2002. Language acquisition: The growth of grammar. Cambridge, MA: MIT Press.

Haegeman, L. 1995. The syntax of negation. Cambridge: Cambridge University Press.

Harves, S. In press. Unaccusativity. In Handbooks of Linguistics and Communication Science: Slavic Languages, 2: 32. Berlin: Mouton de Gruyter.

Harves, S. 2003. Getting impersonal: Case, agreement, and distributive po-phrases in Russian. In W.Browne et al. (eds.), Formal Approaches to Slavic Linguistics, Amherst Meeting, 235254. Ann Arbor: Michigan Slavic Publications.

Harves, S. 2002. Unaccusative syntax in Russian. Ph.D. Dissertation, Princeton University.

Hatakeyama, Y. 1998. Topic- and focus-topicalizations. The Linguistic Review 15, 341-359.

Hiramatsu, K. 1999. Subject and adjunct island asymmetries: Evidence from syntactic satiation. In S. Bird, A. Carnie, J. D. Haugen, and P. Norquest (eds.), Proceedings of the West Coast Conference on Formal Linguistics 18, 183-192. Somerville, MA: Cascadilla Press.

Hiramatsu, K. 2000. Accessing linguistic competence: Evidence from children's and adults' acceptability judgments. Ph.D. dissertation, University of Connecticut.

Huang, C.-T. J. 1982. Move wh in a language without wh-movement. The Linguistic Review 1, $369-416$.

Junghanns, U. and G. Zybatow. 1997. Syntax and information structure of Russian clauses. In W. Browne et al. (eds.), Formal Approaches to Slavic Linguistics 4: Cornell Meeting, 289319. Ann Arbor: Michigan Slavic Publications. 
Jurka, J. 2010. The importance of being a complement: CED effects revisited. Ph.D. Dissertation, University of Maryland.

Kagan, O. 2007. On the semantics of structural case. Ph.D. Dissertation, Hebrew University.

Kallestinova, E. 2007. Aspects of word order in Russian. Ph.D. Dissertation, University of Iowa.

King, T.H. 1995. Configuring topic and focus in Russian. Stanford: CSLI.

Kluender, R. 1998. On the distinction between strong and weak islands: A processing perspective. In P. Culicover and L.McNally (eds.), The Limits of Syntax, 241-269. New York: Academic Press.

Kuroda, S.-Y. 1988. Whether we agree or not: A comparative syntax of English and Japanese. In Papers from the Second International Workshop on Japanese Syntax, ed. W. Poser, 103143. Stanford, CA: CSLI.

Levin, B., and M. Rappaport Hovav. 1995. Unaccusativity: At the Syntax-Lexical Semantics Interface. Cambridge, MA: MIT Press.

Levine, R., and I. Sag. 2003. Some empirical issues in the grammar of extraction. In S. Müller (ed.), Proceedings of the 10th International Conference on Head-Driven Phrase Structure Grammar, 236-256. Stanford, CA: CSLI.

Lohndal, T. 2011. Freezing effects and objects. Journal of Linguistics 47, 163-199.

Merchant, J. 2001. The syntax of silence. Oxford: Oxford University Press.

Nunes, J., and J. Uriagereka. 2000. Cyclicity and extraction domains. Syntax 3, 20-43.

O'Bryan, E. 2003. Event structure in language comprehension. Ph.D. Dissertation, University of Arizona.

Pesetsky, D. 1982. Paths and categories. Ph.D. Dissertation, MIT.

Rizzi, L. 1990. Relativized minimality. Cambridge, MA: MIT Press. 
Rizzi, L. 2001. Relativized minimality effects. In M. Baltin and C. Collins (eds.). Handbook of contemporary syntactic theory, 89-110. Oxford: Blackwell.

Rizzi, L. 2007. On some properties of criterial freezing. CISCL Working Papers on Language and Cognition, 1. StiL Studies in Linguistics, 145-158.

Rizzi, L., and U. Shlonsky. 2007. Strategies of subject extraction. In H.-M.Gärtner and U. Sauerland (eds.). Interfaces + Recursion = Language? Chomsky's minimalism and the view from syntax-semantics, 115-160. Berlin: Mouton de Gruyter.

Rohde, D. 2003. Linger: a flexible platform for language processing experiments, version 2.94.

Ross, J. 1967. Constraints on variables in syntax. Ph.D. Dissertation, MIT.

Sauerland, U., and P. Elbourne. 2002. Total reconstruction, PF movement, and derivational order. Linguistic Inquiry 33, 283-319.

Shapiro, L., E. Zurif, and J. Grimshaw. 1989. Verb processing during sentence comprehension: Contextual impenetrability. Journal of Psycholinguistic Research 18, 223-243

Shetreet, E., N. Friedmann, and U. Hadar. In press. The cortical representation of verbs with optional complements: The theoretical contribution of fMRI. Human Brain Mapping.

Snyder, W. 2000. An experimental investigation of syntactic satiation effects. Linguistic Inquiry $31,575-582$.

Sorace, A. 2000. Gradients in auxiliary selection with intransitive verbs. Language 76, 859-890.

Sprouse, J. 2009. Revisiting satiation: Evidence for an equalization response strategy. Linguistic Inquiry 40, 329-341.

Sprouse, J. and D. Almeida. 2011. The 469 data points that form the empirical foundation of generative syntactic theory are at least $98 \%$ replicable using formal experiments. Ms. University California at Irvine.

http://ling.auf.net/lingbuzz, accessed 6-20-11 
Stepanov, A. 2001. Cyclic domains in syntactic theory. Ph.D. Dissertation, University of Connecticut.

Stepanov, A. 2007. The end of the CED? Minimalism and extraction domains. Syntax 10, 80-126.

Sturgeon, A., M. Polinsky, C. Gomez Gallo, E. Kravtchenko, L.Medova, and V. Koula. 2010. Subject islands in Czech. Paper presented at FASL-XIX, University of Maryland, May 2010 .

Szabolcsi, A., and F. Zwarts. 1993. Weak islands and an algebraic semantics for scope-taking. Natural Language Semantics 1, 235-284.

Takahashi, D. 1994. Minimality of movement. Ph.D. Dissertation, University of Connecticut.

Testelets, J. 2006. Review of S. Karimi, ed. On scrambling. Voprosy jazykoznanija 2006, No 4, $121-128$.

Truswell, R. 2007. Extraction from adjuncts and the structure of events. Lingua 117, 1355-1377.

Uriagereka, J. 1988. On Government. Doctoral Dissertation, University of Connecticut.

Uriagereka, J. 1999. Multiple Spell-out. In S. Epstein and N. Hornstein (eds.), Working Minimalism, 251-282. Cambridge, MA: MIT Press. 
FIGURE 1

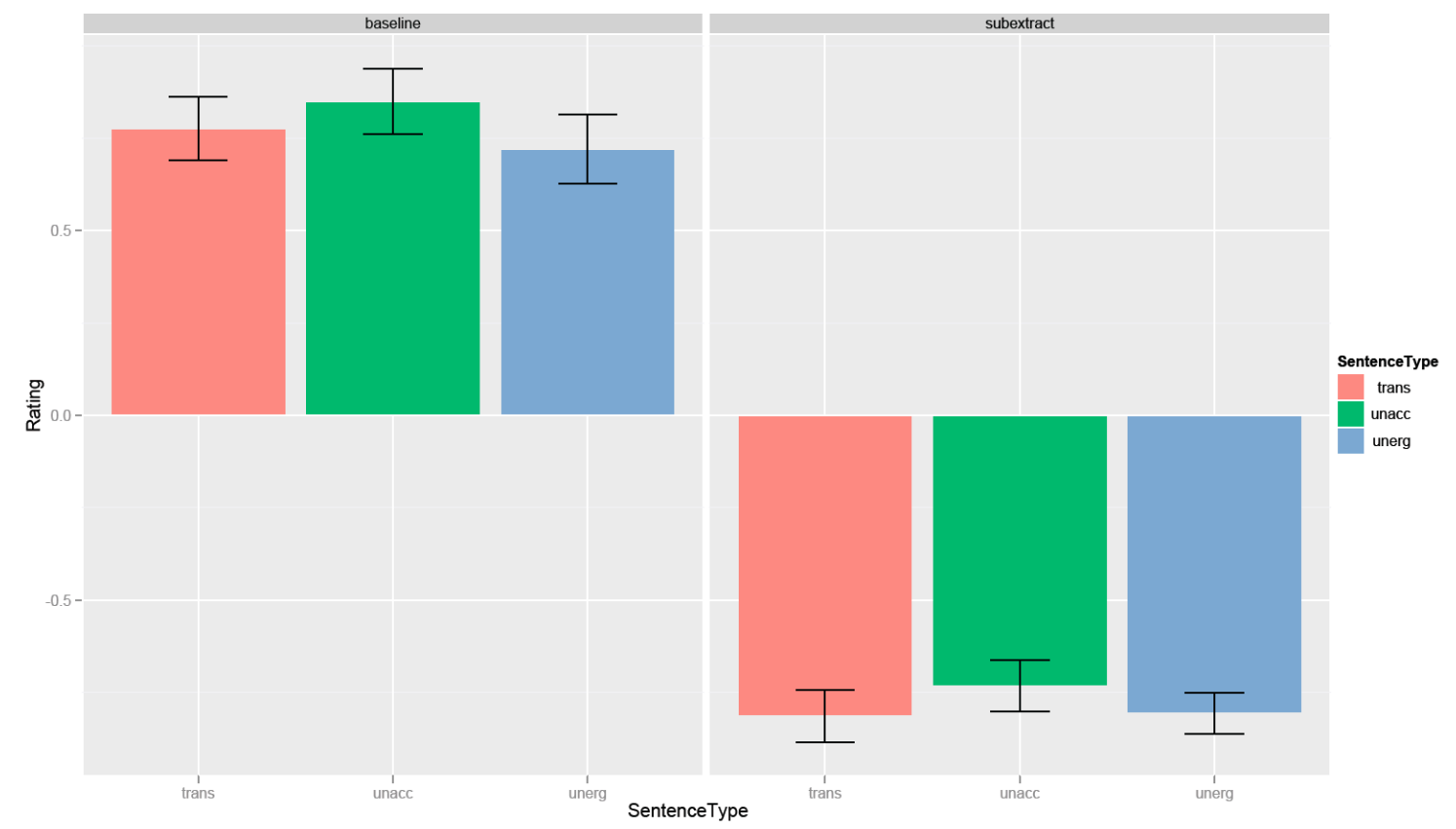

FIGURE 2

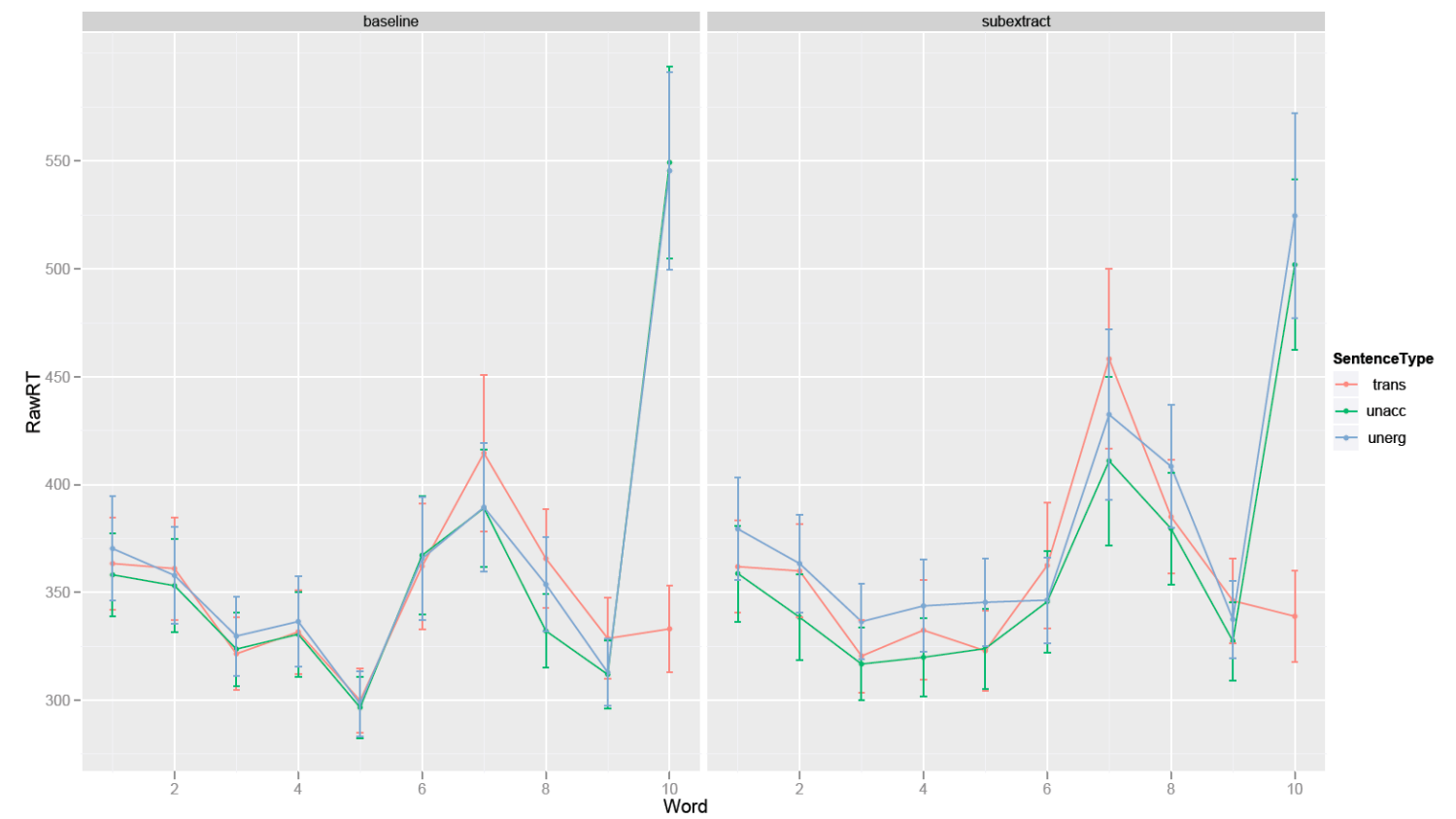

FIGURE3 


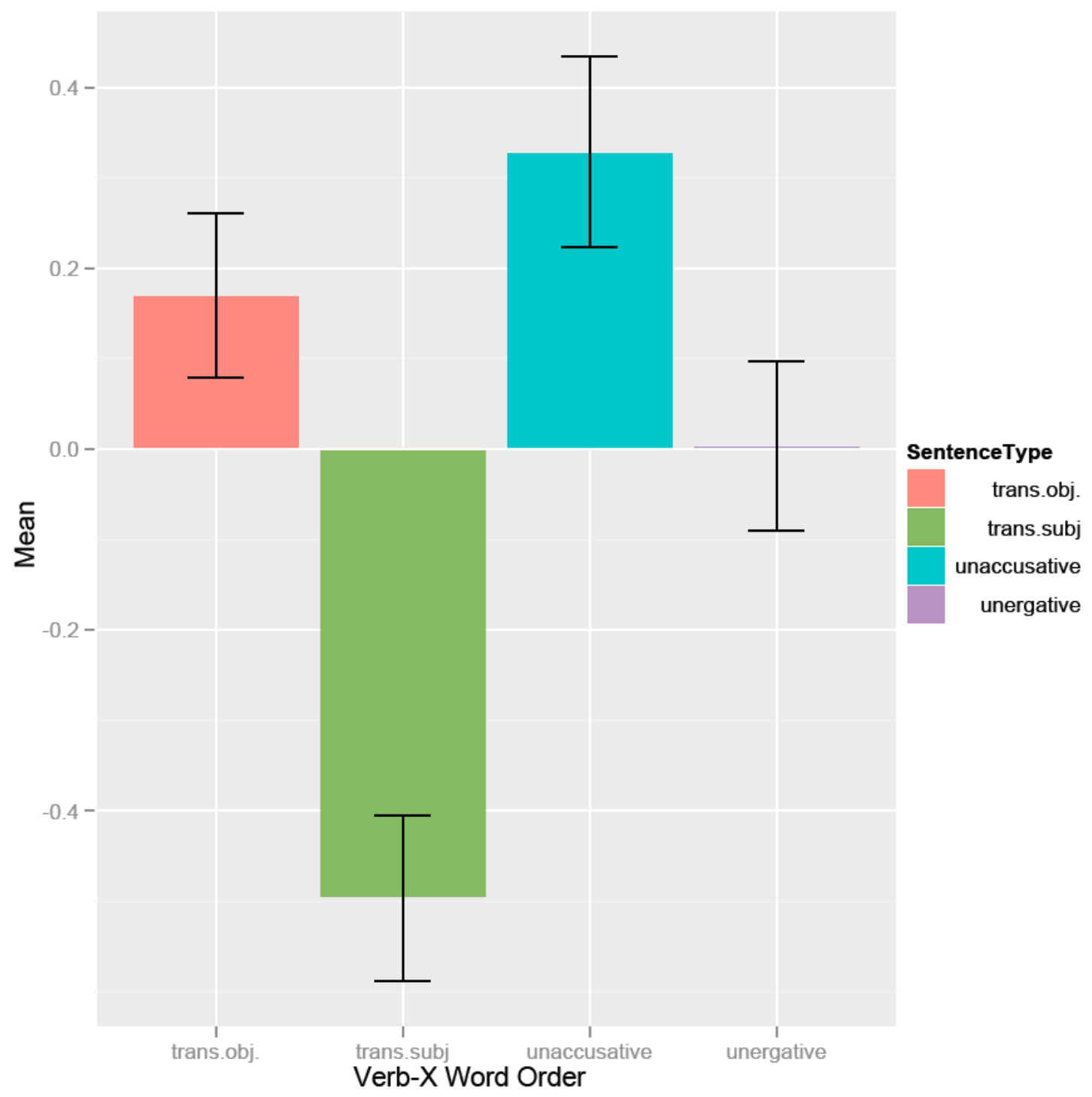

FIGURE 4 


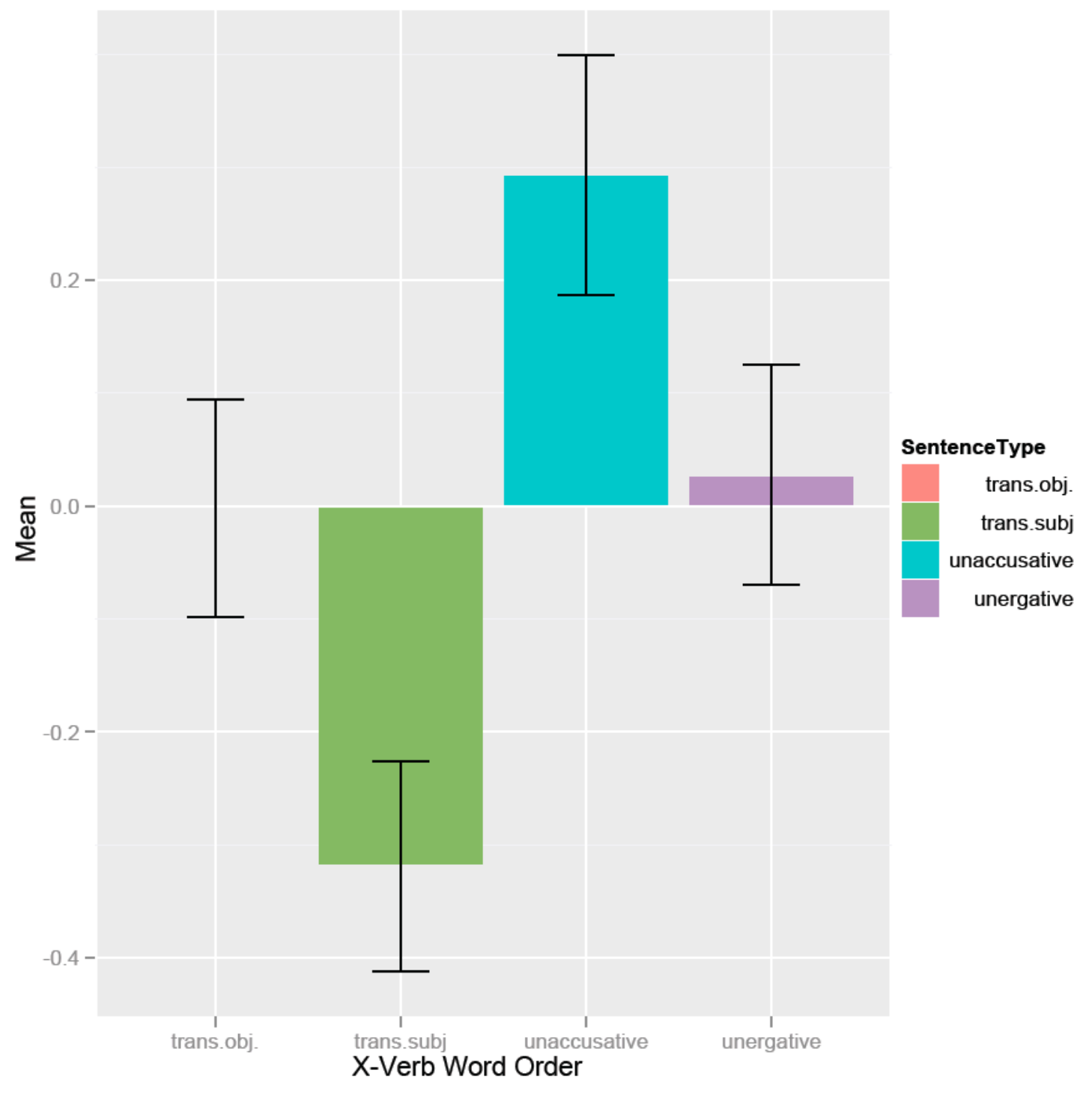

